\section{The importance of using quality indicators in nursing care}

\author{
Opinião dos enfermeiros sobre a utilização dos indicadores \\ de qualidade na assistência de enfermagem \\ La importancia de la utilización de indicadores de calidad en la atención de enfermería
}

\section{Thaizy Valânia Lopes Silveira ${ }^{a}$ \\ Pedro Paulo do Prado Júnior ${ }^{b}$ \\ Andréia Guerra Simanc \\ Marilane de Oliveira Fani Amaro ${ }^{d}$}

\begin{abstract}
Objective: To investigate the opinion of hospital nurses on the use of quality indicators for nursing care.

Method: Research based on the qualitative approach, conducted with 41 nurses from two charity hospitals in Minas Gerais, from September to 0ctober 2013. Interviews with a semi-structured script were used to collect data. The empirical data were organized by means of content analysis.

Results: Indicators are important for assessing the provided care, for improving the quality of care, and for defining strategies to achieve goals.

Conclusions: The difficulties encountered when using these indicators revealed the following constituent elements: lack of time, inadequate number of professionals and lack of knowledge on the subject. It was concluded that nurses understand that indicators are instruments that enable evaluations and improvements, but their understanding of how to use these instruments is incomplete and fragmented.
\end{abstract}

Keywords: Quality indicators, health care. Nursing care. Nursing.

\section{RESUMO}

Objetivo: Investigar a opinião de enfermeiros de instituições hospitalares sobre a utilização dos indicadores de qualidade da assistência de enfermagem.

Método: Pesquisa conduzida pela abordagem qualitativa realizada com 41 enfermeiros de dois hospitais filantrópicos no interior de Minas Gerais, no período de setembro a outubro de 2013. Utilizaram-se entrevistas com roteiro semiestruturado. Os dados empíricos foram organizados mediante análise de conteúdo.

Resultados: Constatou-se que os indicadores são importantes para avaliação da assistência prestada, melhoria da qualidade da assistência e para definição de estratégias para alcançar metas.

Conclusões: Dentro das dificuldades encontradas na utilização dos indicadores, foi possível elencar os seguintes elementos constitutivos: falta de tempo, número inadequado de profissionais e falta de conhecimento a respeito do tema abordado. Conclui-se que os enfermeiros entendem os indicadores como instrumentos de avaliação e melhorias, entretanto, possuem um entendimento incompleto e fragmentado sobre sua utilização.

Palavras chave: Indicadores de qualidade em assistência à saúde. Cuidados de enfermagem. Enfermagem.

\section{RESUMEN}

Objetivo: Investigar la opinión de los hospitales las enfermeras en el uso de indicadores de calidad de los cuidados de enfermería. Las investigaciones realizadas por el enfoque cualitativo realizado con 41 enfermeros de dos hospitales filantrópicos en Minas Gerais en el período septiembre-octubre de 2013.

Método: Se utilizó entrevistas con guión semiestructurado. Los datos empíricos se organizaron de acuerdo con el análisis de contenido. Resultados: Se encontró que los indicadores son importantes para la evaluación de la atención, mejorar la calidad de la atención y el desarrollo de estrategias para alcanzar las metas.

Conclusión: Entre las dificultades encontradas en el uso de indicadores, que era posible enumerar los siguientes componentes básicos: la falta de tiempo, el número insuficiente de profesionales y la falta de conocimiento sobre el tema en cuestión. Llegamos a la conclusión de que las enfermeras entienden los indicadores como herramientas de evaluación y mejoras, sin embargo, tienen una comprensión incompleta y fragmentada de cómo utilizarlos.

Palabras clave: Indicadores de calidad de la atención de Salud. Atención de enfermería. Enfermería.
D0l: http://dx.doi.org/10.1590/1983-

1447.2015.02.47702

\footnotetext{
a Nurse. Resident in Neonatal Care, Sofia Feldman Hospital. Belo Horizonte/MG, Brazil.

${ }^{b}$ Nurse. Master of Health and Environmental Science Education. Lecturer at the Department of Medicine and Nursing (DEM) of the Universidade Federal de Viçosa (UFV). Viçosa-MG, Brazil.

c Nurse. Doctor of Nursing Practice. Faculty Member at the DEM of the UFV. Viçosa-MG, Brazil.

${ }^{d}$ Nurse. Doctor of Cellular and Structural Biology. Faculty Member at the DEM of the UFV. Viçosa-MG, Brazil.
} 


\section{口INTRODUCTION}

The quality of healthcare has been a longstanding concern. In 1854, Florence Nightingale gained popularity as a precursor of measures to establish quality standards by implementing sanitary and care practices during the Crimean War that culminated in a drastic reduction of the mortality rate, from $40 \%$ to $2 \%$, at the hospital in Scu$\operatorname{tari}^{(1-2)}$. However, in the United States, this concern intensified in the early twentieth century and resulted in the foundation of the American College of Surgeons (ACS) that established the Hospital Standardization Program in the mid-1924s ${ }^{(1)}$. During this period, the quality of healthcare was more extensively addressed and reached global repercussions.

In the mid-1950s, the ACS and other associations created the Joint Commission on Accreditation of Hospitals (JCAH) to introduce quality concepts for analyzing cases by means of audits. This commission created indicators, standards and criteria to improve care, and the trinomial "assessment, education and consulting" was subsequently emphasized in an attempt to ensure the quality of healthcare services. In 1988, the JCAH expanded and was renamed the Joint Commission on Accreditation of Healthcare Organizations (JCAHO). Since then, some considerations have been made by Avedis Donabedian in publications that address the quality of healthcare services and how to assess this quality. Also in this period, the International Standards Organization (ISO) created standards for the quality management of organizations ${ }^{(1)}$.

In Brazil, the improvement of quality and the accreditation process became evident in the early 1990s with the creation of the Programa Brasileiro da Qualidade e Produtividade (PBQP), or the Brazilian quality and productivity programme. The goal was to promote the development of economic and social actions with a focus on the quality of services. In 1991, the Programa de Controle de Qualidade Hospitalar (CQH), a hospital quality control programme, was created to evaluate the quality of services provided in hospitals in São Paulo and was later expanded to other states ${ }^{(3)}$.

In the triad of healthcare quality evaluations - structure, process and results ${ }^{(4)}$ - structure represents the physical, human, material and financial resources needed for care; process corresponds to activities involving health professionals and users, including diagnosis, treatment, and ethical aspects of the professional relationship; and result refers to the end product of care, including health, standards and the expectations of users ${ }^{(4)}$.
For the Ministry of Health (MS), quality health is the trademark of modernity and is defined as the degree of compliance with established requirements according to the standards and protocols that organize actions and practices ${ }^{(5)}$. Thus, the measurement of quality is essential to the planning, organization and evaluation of the developed activities. Indicators are one of the tools available to perform this measurement ${ }^{(6)}$.

In light of the current scenario of extensive globalisation, nursing is faced with the dilemma of ensuring quality care through the improvement of scientific technical knowledge ${ }^{(7)}$.

Thus, strategies that make it possible to evaluate healthcare services and results lie in the construction of indicators that target the efficiency and effectiveness of these results ${ }^{(8)}$.

A health indicator is defined as a unit of measurement of an activity to which it is related, or a quantitative measure that can be used as a guide for monitoring and evaluating the quality of essential patient care and service support activities. It identifies and calls attention toward specific results-oriented issues within an organization that must be reviewed; therefore it is not a direct measure of quality ${ }^{(9)}$.

The constant use of indicators helps to improve the quality of care, strengthen the confidence of users, meet the requirements of funding organizations, reduce costs, and stimulate the involvement of professionals ${ }^{(8)}$.

According to the JCAHO, the attributes of indicators are validity, sensitivity, specificity, simplicity, objectivity, and low $\cos ^{(9)}$.

In this sense, quality control based on the analysis of indicators represents a fundamental strategy in the pursuit of reliable care, of well-founded objectivity, and the management of results and quality. As a result, this study was conducted in two educational institutions that seek accreditation, the assurance of quality and patient safety, and use the indicators since 2011 when they joined the ProHosp (Programa de Fortalecimento e Melhoria da Qualidade dos Hospitais SUS/MG), a programme for the strengthening and improvement of quality in public hospitals.

However, practical classes in nursing management carried out with students of the seventh nursing period with the nurses of these institutions revealed that in practice these indicators were underutilized.

In light of these observations, the guiding question of this study was: what is the opinion of hospital nurses on the use of quality indicators for nursing care?

Therefore, the aim of this study is to investigate the opinion of hospital nurses on the use of quality indicators for nursing care. 


\section{METHODOLOGY}

Research with a qualitative approach conducted at two charity hospitals; one with 112 beds and 22 nurses, and another with 103 beds and 19 nurses. All the hospitals of a municipality in the interior of Minas Gerais, Brazil were included in this study.

These sites were selected because they are educational institutions linked to a federal university in the region. They have also initiated actions geared toward quality, risk management and patient safety, which reveals a commitment with well-founded results. These institutions have been seeking accreditation and using indicators since 2011, when they joined the Pro-Hosp. They also work with various quality indicators collected by the nursing staff that are subsequently analyzed and evaluated by nurses and technical manager.

The population comprised all of the nurses of these institutions, totalling 41 individuals. They all participated in one or more of these steps: collection, analysis and/or evaluation of the indicators. The inclusion criterion was nurses who worked with direct patient care. The exclusion criterion was nurses who were on leave for any reason. However, none of the professionals fit the exclusion criterion.

Data were collected from September to October 2013 using a semi-structured interview script. The interviews were recorded and transcribed in full, and contained the following guiding questions: What are the main nursing quality indicators used at the hospital? What is the importance of these indicators and which factors hinder the use of these indicators?

The results were analyzed using the content analysis technique, which proposes a sequence with three chronological cores: pre-analysis, material exploration and pro- cessing of results, and inference and interpretation ${ }^{(10)}$. The interviews were scanned and then thoroughly read to ensure familiarity with the text and understand the message the subject wanted to convey. We then proceeded to thematic selection to identify the core meaning or semantically similar elements. The final step was categorization in the light of literature ${ }^{(10)}$.

The research was approved by the Ethic Committee for Research with Human Beings of the Federal University of Viçosa, CAAE n 17386513.8.0000.5153, and the ethical precepts for the realization of this study observed Resolution $466 / 12$ of the National Health Council that supported the creation and signature of the informed consent statement. Prior to the start of research, authorization was requested at the hospital boards. Approval was granted by the Research Ethics Committees of both hospitals.

To ensure the anonymity of the subjects, the interviews were numbered according to the sequence in which they occurred.

\section{RESULTS AND DISCUSSION}

A total of 41 nurses participated in this study. Most of the participants were women (76\%), which is common in nursing due to historical events. The social division of nursing practices granted women the responsibility of caring for patients, children and the elderly(11). The age of the participants ranged from 24 to 46 years, with the prevalence of young people (44\% were aged between 24 and 30 years). The average training period was one to five years, with a maximum of 20 years. In relation to studies, $83 \%$ of the professionals had completed a postgraduate course, with a predominance of Intensive Therapy (29\%).

Table 1 - Main nursing care quality indicators used by nurses of two teaching hospitals in the interior of Minas Gerais, Brazil, 2013

\begin{tabular}{llc}
\multicolumn{1}{c}{ Nursing care quality indicators } & Percentage & Type \\
\hline Incidence of Bed Sores & $\mathbf{( \% )}$ & Process \\
Incidence of Loss of Naso-Gastric Enteral Feeding Tubes & $18 \%$ & Process \\
Rate of Infection of Indwelling Urinary Catheters & $15 \%$ & Process \\
Incidence of Accidental Extubation & $15 \%$ & Process \\
Incidence of Patient Falls & $11 \%$ & Process \\
Rate of Infection by Central Venous Catheter & $11 \%$ & Process \\
\hline
\end{tabular}

Source: Research data, 2013. 
With respect to nursing care quality indicators, only $54 \%$ of the nurses had used this method to guide their practices. Curiously, $46 \%$ of the nurses claimed they collected and analysed the indicators, but did not make use of result evaluations to implement improvements in the sectors in which they worked. They claimed to use the metrics, but did not employ a qualitative approach for the investigated phenomena.

The main nursing care quality indicators used by nurses at both institutions are shown in Table 1, and 100\% of these indicators are classified as process indicators.

It is observed that, according to the $\mathrm{CQH}$, the created quality indicators for good nursing practices can be applied and can portray the reality of nursing services. Moreover, an evaluation requires a minimal number of indicators that can reveal the main characteristics of the reality of the health service and its practices ${ }^{(12)}$. It is worth mentioning that the identified key indicators are defined as data or numeric information that seeks to quantify the performance of nursing services and processes. Indicators that evaluate the structure or results of the provided services were not reported.

With regard to the opinion of the nurses on the importance of using nursing care quality indicators, the participants stressed the following constitutive elements in their statements: assessing the provided service, improving the quality of care and defining strategies to reach goals.

The category evaluating nursing care was evident in the following statements:

I think it's important to be able to assess our own work, to see how it's being accepted by others as well, if it's working $[\ldots]^{(1)}$.

Because you use the indicator to evaluate the quality of your service. Are you providing a quality service? What can be improved? What is working well? The indicator will show you all this ${ }^{(9)}$.

It serves as a quality meter for us. These indicators help us see how that work is progressing, how it's administered, what the responses are ${ }^{(12)}$.

The indicators are considered instruments to measure the quality of healthcare because they help to identify faults in the process, but the action of measuring alone is not enough. It must be the first step toward establishing standards of excellence and the continuous improvement of care. According to JCAHO, the indicators can be used as a guide for monitoring and evaluating care and the activities of a service ${ }^{(1)}$. The nurses showed that they have a correct understanding of the real importance of quality indicators, as illustrated below:

I think... they best analyze the standards, so to speak. They have to have a practical application. Based on my experience, oftentimes, some indicators are created for scientific purposes, to collect data. But they do not necessarily focus on the quality of care ${ }^{(29)}$.

I think it's no good just to collect indicators if we don't have, let's say, a real use for them ${ }^{(37)}$.

However, it was observed that the nurses do not always use the indicators to improve care, and seem to stall at the stage of collecting or monitoring and analysis without reaching the stage of implementing actions. Measurements should not be merely regarded as an interesting methodological exercise. They must enable the improvement of health practices by establishing working standards and reference points for continuous enhancements ${ }^{(13)}$.

Another category identified in the statements of the nurses about the importance of using quality indicators was improving the quality of care. Below, some of the statements:

It is useful because it helps to improve our routine, improve the service that we provide to patients, I think a lot of it is valid ${ }^{(10)}$.

By analysing the indicators, you can see the points we need to improve, the points we don't need to improve, complete an evaluation process, what's working, what isn't working, what we can improve, the critical points ${ }^{(13)}$.

In my view, the importance of using them is ... we can detect the points that should be outlined, the points we should emphasize or even to fix errors, improve the care that we will provide, so we become aware of the risks to our patients and our practices can improve ${ }^{(27)}$.

It is very important, it helps to improve care. The problem is that the indicators are evaluated, but they are not always carried out. It's really important! Because it is a tool and an instrument we can use to improve care ${ }^{(32)}$.

The nurses showed that they are aware that indicators are instruments to improve healthcare practices and moni- 
tor the quality of assistance. However, they seemed unable to incorporate all the stages of indicator management and did not always know what to do with the numbers. It should be noted that the desire to improve the quality of care should be a collective attitude, rather than an isolated attitude. This requires the implementation of a quality policy in the organizations and greater commitment at management level.

Quality indicators are tools that can be used to improve the quality of care by identifying intervening factors in the work processes of nursing teams. This identification can guide actions to revert the detected scenario and support analysis of non-compliance with standards that are considered desirable. It can also guide attention toward the key points of care that must be reviewed ${ }^{(14)}$.

The category defining strategies to reach goals emerged from the following statements:

We have goals in the indicators. If we haven't reached our goal, we have to know why we didn't reach it and find a justification. Right... We have to explain why we didn't reach that goal. And try to improve(15).

Then, when it solely depends on care, we need a critical analysis and we make suggestions, and from those suggestions we work and try to reach the goals. It's a guide that helps me analyse what is working, what I can improve, what depends on care, what depends on the hospital, what my goal is, and it directly influences the quality of care $e^{(16)}$.

It should be noted that the information obtained with the quality indicators can be used for the subsequent evaluations and adjustments of goals that target the best possible quality and result in better management ${ }^{(15)}$. The implementation of indicators should be considered a critical factor for management and for transforming healthcare, education and research. The information extracted from these data helps to recognize, document and evaluate a given situation and support decision making. The internal comparison, such as between sectors, and the external comparison, between different services, helps to review goals and present and future decisions ${ }^{(15)}$.

The statements reveal the difficulties that nurses encounter when they use quality indicators in nursing services. The statements allowed the detection of the following constitutive elements: lack of time, inadequate number of professionals and lack of knowledge on the subject.
The nurses considered lack of time as a factor that hindered the implementation of all the stages of indicator management:

Lately it's been more about having time for us to sit down and actually do it. Because, in this case, we are responsible for three sectors during the week. The weekend comes and we are responsible for five sectors, so it's difficult for us to sit and do it $t^{(2)}$.

When the pressure increases, I manage to sit and fill in the numbers, but I don't have time to think about the data ${ }^{(12)}$.

[...] It's a lot of forms to fill out. We have way too much paperwork. It's difficult, because sometimes it takes time we don't have, but that's all really ${ }^{(15)}$.

[...] Sometimes, it's a question of time, and we have to attend to the urgent things and the things that aren't urgent are put in the back burner ${ }^{(31)}$.

The statements showed that the biggest challenge is not merely to understand the importance of the indicators or of obtaining good indicators, but whether to maintain and improve them. The debate on the lack of time can be related to demands of the care that patients require and the number of professionals hired by the institutions ${ }^{(16)}$. In this context, another frequently mentioned aspect was the inadequate number of professionals, which reveals an excessive word load that directly affects the results of quality healthcare.

It's quite tough in our sector because there are only two nurses $[\ldots]^{(3)}$.

The work load here is huge. We have to deal with this entire sector. We don 't have time to do those little things $\left[{ }^{. . .}\right]^{(4)}$.

I can talk about my sector, and the work load is huge.... ${ }^{(5)}$.

Sometimes, we have to work as secretaries and answer the phone, talk to the family because sometimes there is no psychologist or other professionals ${ }^{(39)}$.

The workload of the nursing staff and the lack of workers compromises quality, which has repercussions on the infection rate and the mortality rate ${ }^{(17)}$.

The reduced number of workers in the nursing unit is considered a hindrance for the use of quality indicators and for the performance of other activities in the work process. 
A study conducted at the surgical centre of a large hospital identified that a reduced number of nurses hinders the systemization of perioperative nursing $\operatorname{care}^{(18)}$. In light of so much evidence, it was observed that a reduced number of nursing professionals prevents the implementation of quality and safety actions. Consequently, the administration of institutions should become more aware of this demand in order cause a more positive impact for the institution, its professionals and its users.

Another difficulty mentioned by the nurses was the lack of knowledge regarding the indicators. The participants reported difficulties in using the quality indicators because they lacked knowledge on how to apply the indicators. The indicators should therefore be easy to understand by the users of the information. The importance of the using indicators is justified by the need to monitor and measure their results, to verify alignment with the goals of the institution, and the possibility of assessing the planned actions for the achievement of goals. They need to be generated and handled on a regular and systemic basis so they can become a valuable tool for evaluation and management ${ }^{(15)}$. This situation was revealed in the following statements:

The lack of knowledge $e^{(11)}$.

... the problem of professionals that do not understand the importance of this, so they don't support it ${ }^{(13)}$.

When you don't have the knowledge, it gets harder and more time-consuming. If you know how to use them, it's quicker and more practical to do(26).

It's all about knowing exactly how to do it. To do it anyway, at the end of our shift we just fill in the indicators, but sometimes, we don't know why or what it's for, or the results that it will bring later ${ }^{(23)}$.

A study conducted in Montes Claros, MG, identified the difficulties in using indicators for evaluating the quality of results and the lack of theoretical and practical knowledge of this methodology in the health services, which reflects on the responsibility of health institutions in improving continued education programmes ${ }^{(15)}$.

\section{口CONCLUSION}

This study showed that nurses understand that the indicators are instruments to evaluate and improve care. However, their knowledge of how to use these indicators and their importance for the assurance of quality nursing care was incomplete and fragmented. The statements showed that a small number of professionals used the results of these indicators to implement improvements in their sectors.

The nurses realized that their working conditions directly reflect on faults in the work process, since the main difficulties they pinpointed when using the indicators were lack of time, a reduced number of professionals and lack of knowledge on the subject.

In order to change this reality, health institutions should become aware of the need to increase the number of nursing professionals and prioritize continued education in order to prevent faults related to knowledge of the indicators from compromising their use.

With respect to the limitations of this study, the fact that it was conducted in two hospitals does not express the situations of other municipalities. New studies should therefore be conducted to better generalize the results.

\section{Q REFERENCES}

1. Cunha, KC. Gerenciamento na enfermagem: novas práticas e competências. $1^{\mathrm{a}}$ ed. São Paulo: Martinari; 2008.

2. Kurcgant P. Gerenciamento em enfermagem. 3a ed. Rio de Janeiro: Guanabara Koogan; 2012.

3. Tronchin DMR, Melleiro MM, Mota NVYP. Indicadores de qualidade de enfermagem; uma experiência compartilhada entre instituições integrantes do "Programa de Qualidade Hospitalar". O Mundo da Saúde. 2006;30(2):300-5.

4. Donabedian A, Wheeler JRC, Wyszewlanski L. Quality, cost and health: an integrative model. Medical Care. 1982;20:975-92.

5. Ministério da Saúde (BR). Avaliação para melhoria da qualidade da estratégia saúde da família: documento técnico. Brasília; 2006.

6. Moura GMSS, Magalhães AMM. Atuação do enfermeiro a partir dos resultados dos indicadores. In: Vale EG, Lima JR, Feli VEA, organizadores. Programa de atualização em enfermagem: gestão. Porto Alegre: Artmed; 2011.

7. Vituri DW; Matsuda LM. Validação de conteúdo de indicadores de qualidade para avaliação do cuidado de enfermagem. Rev Esc Enferm USP. 2009;43(2):429-37.

8. Kurcgant $P$, Tronchin DMR, Melleiro MM. A construção de indicadores de qualidade para a avaliação de recursos humanos nos serviços de enfermagem: pressupostos teóricos. Acta Paul Enferm. 2006;19(1):88-91.

9. Joint Commission on Accreditation of Healthcare Organization (US). Characteristics of clinical indicators. QRB Qual Rev Bul. 1989;15(11):330-9.

10. Bardin L. Análise de conteúdo. Lisboa: Edições 70; 2008.

11. Cintra EA, Pinto AC, Sousa EO, Rosa EV, Lima IA, Rodrigues SO. Utilização de indicadores de qualidade para avaliação da assistência de enfermagem: opinião dos enfermeiros. J Health Sci Inst. 2010;28(1):29-34.

12. Duarte IG, editor. $3^{\circ}$ caderno de indicadores CQH. São Paulo; 2009. Programa $\mathrm{CQH}$ 
13. Franco JN, Barros BPA, Vaidotas M, D'Innocenzo M. Percepção dos enfermeiros sobre os resultados dos indicadores de qualidade na melhoria da prática assistencial. Rev Bras Enferm. 2010;63(5):806-10.

14. Labbadia LL, D'Innocenzo M, Fogliano RRF, Silva GEF, Queiroz RMRM, Carmagnani MIS, et al. Sistema informatizado para gerenciamento de indicadores da assistência de enfermagem do Hospital São Paulo. Rev Esc Enferm USP. 2011;45(4):1013-7.

15. Menezes PIFB, D'Innocenzo M. Dificuldades vivenciadas pelo enfermeiro na utilização de indicadores de processos. Rev Bras Enferm. 2013;66(4):571-7.
16. Simões SC, Gabriel CS, Bernardes A, Évora YDM. Opinião do enfermeiro sobre indicadores que avaliam a qualidade na assistência de enfermagem. Rev Gaúcha Enferm. 2009;30(2):263-71.

17. Needleman J, Buerhaus P, Pankratz VS, Leibson CL, Stevens S, Harris M. Nurse staffing and inpatient hospital mortality. New Engl J Med. 2011 Mar;364(11):1037-45.

18. Stumm EMF, Maçalai RT, Kirchner RM. Dificuldades enfrentadas por enfermeiros em um centro cirúrgico.Texto Contexto Enferm. 2006 jul-set;15(3):464-71.

\section{Author's address:}

Marilane de Oliveira Fani Amaro

Universidade Federal de Viçosa

Avenida Peter Henry Rolfs, s/n

36570-900 Viçosa - MG

E-mail:marilaneamaro@yahoo.com.br
Received: 06.06.2014

Approved: 29.04.2015 